УДК 37.012 .8

DOI: $10.15330 /$ esu. 17. 333-338
Оксана Кондур,

доктор педагогічних наук, доцент, ДВНЗ "Прикарпатський національний університет імені Василя Стефаника" (м. Івано-Франківськ, Україна)

Oksana Kondur,

Doctor of pedagogical sciences, Associate Professor, Vasyl Stefanyk Precarpathian National university (Ivano-Frankivsk, Ukraine)

oksana.kondur@pnu.edu.ua

\section{Наталія Фучинська,}

викладач, Коломийський економіко-правовий коледж (м. Коломия, Україна)

Nataliia Fuchynska,

Teacher, Kolomyja College of Economics and Law

(Kolomyja, Ukraine)

fnataliia@yahoo.com

\title{
ПЕДАГОГІЧНА ДІАГНОСТИКА ЯК ЧИННИК ЗАБЕЗПЕЧЕННЯ ЯКОСТІ ОСВІТНЬОГО ПРОЦЕСУ
}

\section{THE PEDAGOGICAL DIAGNOSTICS AS A FACTOR FOR ENSURING THE QUALITY OF THE EDUCATIONAL PROCESS}

Аналіз наукової та методичної літератури дозволяс стверджувати про актуальність педагогічної діагностики як наукової проблеми. Існують різні підходи до визначения сутності педагогічної діагностики як з позичій змісту діагностичної діяльності, так із позичій мети та завдань, які перед пею ставляться. В умовах модернізачії освіти діагностику знань та вмінь здобувачів освіти необхідно розглядати як обов 'язковий компонент освітнього прочесу, за допомогою якого визначасться рівень досягиения поставлених навчальних чілей та забезпечусться якість освіти.

Сучасні вимоги до педагогічної діагностика потребують застосування нових інформачійних технологій. Завдяки розвитку та поширенню освітніх онлайн сервісів дочільне їх використания в педагогічній діагностичі.

Ключові слова: освітній прочес, педагогічна діагностика, методи діагностики, якість освіти, інформачійні ресурси контролю знань.

The analysis of scientific and methodological literature allows us to confirm the relevance of pedagogical diagnostics as a scientific problem. There are different approaches to defining the essence of pedagogical diagnostics, both in terms of the content of the diagnostic activity and in terms of the purpose and tasks that are set before it. In the context of the modernization of education, the diagnosis of knowledge and skills of the recipients of education should be considered as a mandatory component of the educational process, which determines the level of achievement of educational goals and quality of education.

The problem area of pedagogical diagnostics is much broader than the traditional assessment of the teacher's knowledge, skills and even personal qualities. Pedagogical diagnostics should be interpreted as a system of accurate identification of the results of the didactic process, which includes control, verification, evaluation, accumulation of statistics, their analysis, forecasting, dynamics, tendencies of the educational process.

Modern requirements for pedagogical diagnostics require the use of new information technologies. Due to the development and distribution of educational online services, it is advisable to use them in pedagogical diagnostics. Among the most common information resources is the use of platforms for testing on the Internet. Because well-chosen and structured test tasks allow you to determine the level of knowledge and skills of the educational process. In addition, such online resources are characterized by mobility and accessibility. 
Key words: educational process, pedagogical diagnostics, methods of diagnostics, quality of education, information resources of knowledge control.

Постановка проблеми у загальному вигляді та ії зв'язок із важливими науковими чи практичними завданнями. В умовах реформування системи української освіти, підвищення вимог до іiі якості, діагностика знань здобувачів освіти, як механізм неперервного відстеження результатів навчання, передбачає не тільки контроль за рівнем засвоєння навчального матеріалу, але й з'ясування причин появи прогалин в знаннях, коригування навчальної діяльності, забезпечення рефлексії. Важливо оцінити результативність навчання здобувача освіти задля виявлення можливостей підвищення якості освітньої діяльності.

Аналіз останніх досліджень і публікацій. Діагностика знань та вмінь здобувачів освіти завжди знаходиться у центрі уваги науковців і практиків, оскільки вона $є$ джерелом інформації для організації ефективного навчального процесу. Вагомий внесок у розробку теоретичних, організаційно-методичних та методологічних положень щодо діагностики та контролю знань та вмінь суб'єктів навчальної діяльності здійснили такі науковці, як В. Андреєв, В. Андрущенко, В. Безпалько, Н. Бібік, В. Гладуш, М. Гончаренко, Л. Кондратенко, О. Кочетов, В. Кремень, С. Максимюк, О. Орлов, В. Паламарчук, Дж. Рассел, О. Савченко, П. Сікорський, М. Фіцула, В. Ягупов, О. Ярошенко та інші.

Виокремлення невирішених раніше аспектів загальної проблеми. Уніфікація суті поняття "діагностика", шляхи удосконалення процесу діагностики знань та вмінь залишаються недостатньо розробленими і потребують уточнення відповідно до сучасних вимог.

Постановка завдання. Мета статті полягає у дослідженні трактувань педагогічної діагностики, їх узагальнення з урахуванням сучасних вимог.

Виклад основного матеріалу дослідження.

На сучасному етапі реформування освіти діагностику знань та вмінь варто розглядати як: 1) обов'язковий компонент освітнього процесу, за допомогою якого визначається рівень досягнення поставлених навчальних цілей, 2) актуальну наукову проблему $з$ огляду на кардинальні зміни, що відбуваються у освітньому просторі України.

Проведеного дослідження щодо сутності діагностики знань учнів дають підстави стверджувати про актуальність педагогічної діагностики як наукової проблеми. Існують різні підходи до визначення сутності педагогічної діагностики: одні трактують іiі з позицій змісту діагностичної діяльності, інші - відповідно до мети педагогічної діагностики і завдань, які стоять перед нею.

Як вітчизняні, так зарубіжні науковці приділяють багато уваги теоретичним та практичним аспектам педагогічного діагностування. Вивчення наукових джерел дозволяє зробити висновок, що серед науковців питання визначення поняття "педагогічна діагностика" є дискусійним. Зокрема, В. С. Аванесов вважає, що "педагогічна діагностика $€$ процесом, націленим на створення наукових методів отримання об'єктивованих оцінок поточної і підсумкової підготовленості учнів та студентів" [1, с. 182]; О. С. Андрієнко під педагогічною діагностикою/педагогічним діагностуванням розуміє “процес, який дозволяє оцінити навчально-виховну діяльність педагога і допомагає у виявленні необхідних напрямків підвищення ефективності цієї діяльності” [2]; Т. Є. Кристопчук стверджує, що “діагностика - це з'ясування всіх обставин та визначення результатів дидактичного процесу. Мета дидактичного діагностування полягає у своєчасному виявленні, оцінюванні та аналізі перебігу навчального процесу у зв'язку 3 його продуктивністю" [8, с. 44]; Карл Інгенкамп трактує педагогічну діагностику як процес, у ході якого за допомогою наукових критеріїв якості викладач/вчитель "стежить за учнями i проводить анкетування, обробляє дані спостережень й опитування i повідомляє одержані результати з метою описання поведінки, пояснення іï мотивів чи передбачення поведінки в майбутньому" [6, с. 55]. Загалом, сучасні дослідники вважають педагогічну діагностику процесом, впродовж якого проводяться 
- “виміри рівня засвоєння знання, навченості тих, кого навчають, а також і деяких сторін розвитку особистості та виховання,

- обробка та аналіз отриманих знань,

- узагальнення і висновки про коригування процесу навчання i про рух учнів на наступні рівні навчання,

- висновки про ефективність всього освітнього закладу" [9, с. 63].

Варто зазначити, що науковці і методисти-практики дотримуються поглядів, згідно з якими контроль знань, вмінь та навчальних досягнень здобувачів освіти $\epsilon$ тільки фіксуванням результатів навчально-пізнавальної діяльності учнів, без роз'яснення ïx походження. Діагностика ж з'ясовус умови і обставини, в яких відбувається освітній процес.

Процес діагностування знань суб'єктів навчання дає можливість отримати інформацію щодо причин, які сприяють чи перешкоджають досягненню бажаних навчальних результатів. Адже педагогічна діагностика - це "система якісних i кількісних характеристик ефективності функціонування та тенденцій саморозвитку освітньої системи, включаючи їі цілі, зміст, форми і методи, дидактичні та технічні засоби, умови і результати навчання, виховання та саморозвитку особистості. Таким чином, проблемне поле педагогічного діагностування значно ширше, ніж традиційна оцінка знань, умінь і навіть особистих якостей того, хто навчається". [2]

Отже, на підставі узагальнення тлумачень багатьох вчених, педагогічна діагностика - це система точного виявлення результатів дидактичного процесу, яка включає контроль, перевірку, оцінювання, накопичення статистичних даних, їх аналіз, прогнозування, вияв динаміки, тенденцій навчального процесу (рис.1.)

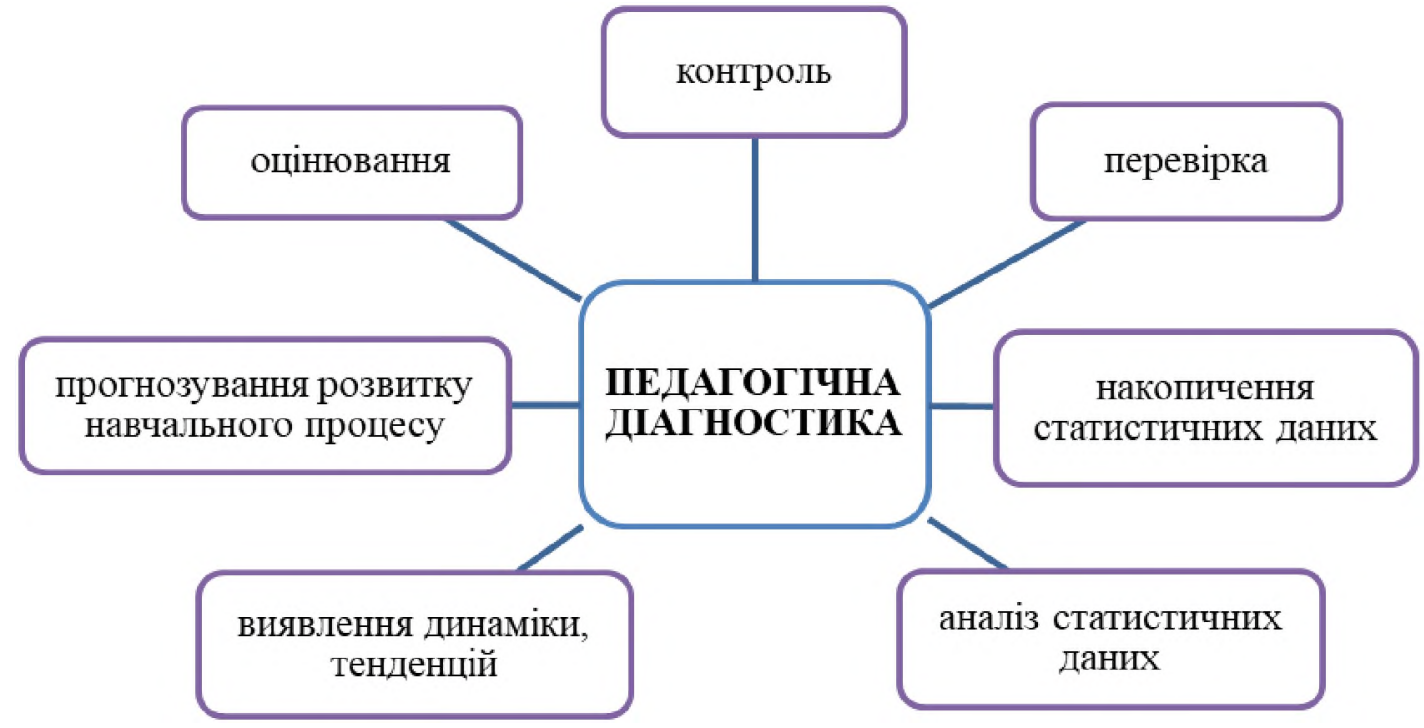

Рис.1. Складові компоненти діагностики

Діагностика засвоєння знань і формування умінь в здобувачів освіти $є$ важливою в організації навчального процесу, оскільки дозволяє викладачу/вчителю отримати необхідну інформацію для подальшого управління навчально-пізнавальною діяльністю студентів/учнів. Від об' єктивності та повноти цієї інформації залежить якість навчання. Традиційні форми та засоби контролю успішності здобувачів освіти в основному використовують для отримання інформації про підсумки навчання, але не дають в повній мірі реалізувати діагностичну функцію моніторингу, яка полягає у виявленні причин допущених помилок здобувачами освіти. Тому правильною $є$ позиція науковців, які вивчають педагогічну діагностику як педагогічну діяльність, спрямовану на 
керування навчальним процесом. Діагностуючі дії повинні бути взаємопов'язані і спрямовуватися на визначення невикористаних можливостей. Проведене викладачем/вчителем діагностування повинне відображатись у його педагогічній діяльності та мати позитивний вплив на розв'язання наявних проблем у навчальному процесі. Тобто педагогічна діагностика - це теоретична основа професійного зростання викладача/ вчителя, удосконалення його дидактичної діяльності..

Очевидно, що діагностування - це невід'ємна частина освітнього процесу. Його основні завдання:

- визначення рівня засвоєння здобувачами освіти знань, умінь і навичок;

- підтвердження успішності результатів навчання;

- планування наступних етапів функціонування системи “викладач-студент"/ “вчитель-учень";

- прогнозування та коригування освітнього процесу.

За допомогою детальної діагностики результатів навчання можна завчасно виявляти “прогалини" в знаннях та вміннях здобувачів освіти, надавати їм своєчасну консультативну підтримку, актуалізувати їх увагу на вивченні певного матеріалу та оволодінні відповідними навичками, що забезпечує реалізацію цілей педагогічного діагностування та сприяє підвищенню якості освіти (рис.2).

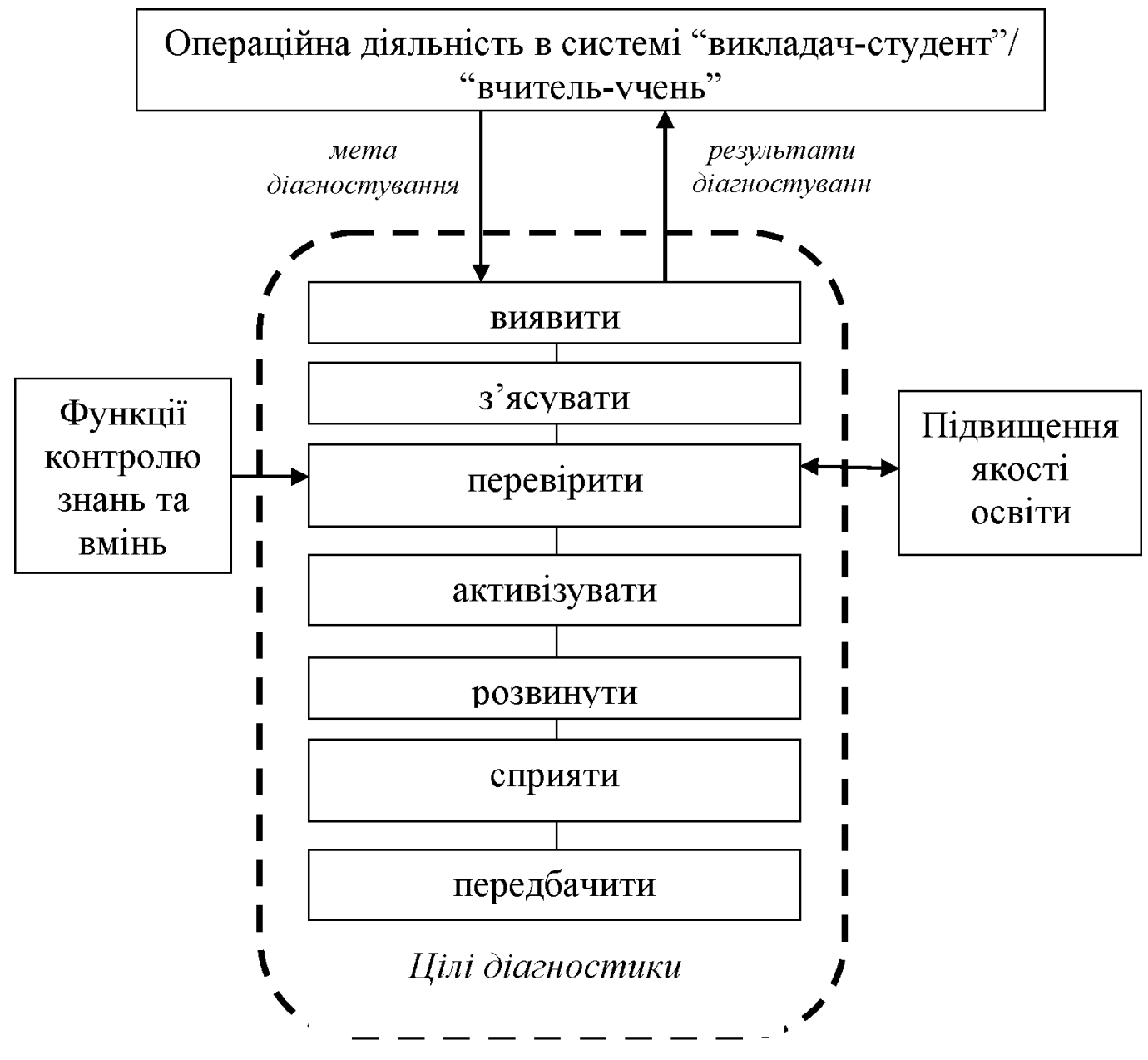

Рис.2. Реалізація цілей педагогічної діагностики.

Сучасні вимоги до діагностика рівня засвоєння здобувачами освіти системи знань і вмінь потребують застосування нових інформаційних технологій (див.[3-5; 
10]). Стрімкого розвитку та поширення набувають онлайн сервіси, використання яких доцільне з завдяки їх мобільність і доступність (див. рис.3).

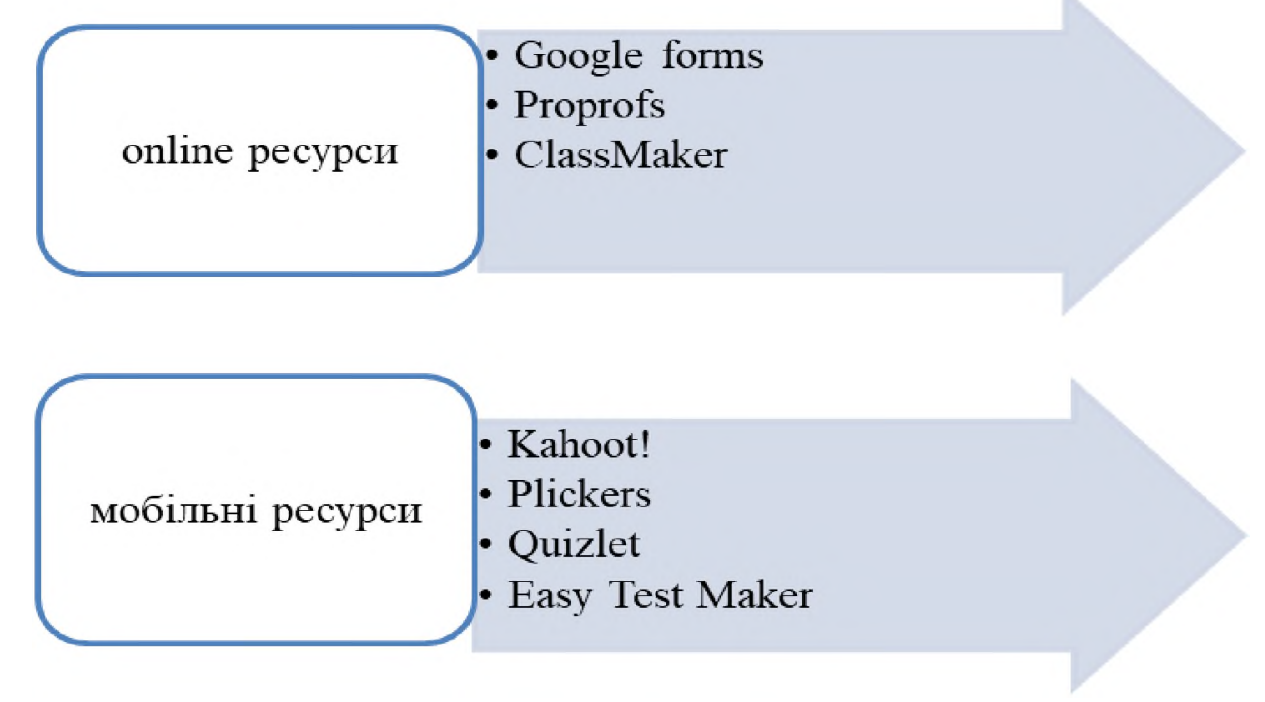

Рис.3. Сучасні інформаційні ресурси тестової перевірки знань.

Висновки. Модернізація освіти України та ті виклики, які стоять перед країною в умовах інтеграції у світовий освітній простір, зумовлюють перегляд пріоритетності завдань та висувають до якості освітнього процесу. Контроль знань, вмінь та навчальних досягнень учнів в науковій літературі визначається як констатація результатів навчально-пізнавальної діяльності учнів без роз'яснення їх походження. На відміну від цього, педагогічна діагностика - як процес з'ясування умов і обставин, в яких проходить навчальна діяльність. Це зумовлює актуальність педагогічної діагностики, яку необхідно тлумачити як сукупність методів і форм контролю, перевірки рівня знань та вмінь, набутих здобувачами освіти в процесі навчальної діяльності. Крім цього, до складових діагностики входить прогнозування та планування навчального процесу, удосконалення педагогічної майстерності викладача і вчителя. Тому педагогічне діагностування забезпечує якість освітнього процесу загалом.

\section{Література}

1. Аванесов В. С. Форма тестовых заданий.- Москва: Центр тестирования, 2006. - 156 c.

2. Андрієнко О. С. Діагностування в навчальному процесі // Вісник Запорізького державного університету. - 2002.- №1.- С. 1-5.

3. Генсьорська М. М. Адаптивне тестування в освіті // Інформаційно-комунікаційні технології в освіті. - 2014, №1.

4. Гладка Л.І. Системний підхід до оцінки якості знань у формі комп'ютерного тестування [Електронний ресурс]. - Науковий вісник Донбасу. - 2014. - Режим доступу: http://nvd.luguniv.edu.ua/archiv/NN26/index.html.

5. Єремеєвич М. О. Комп'ютерні системи тестування знань та їх аналіз / //Молодий вчений. 2016. - C. 330-332.

6. Ингекамп К. Педагогическая диагностика [пер. с нем.] - М. : Педагогика, 1991. - 240 с.

7. Корницька Ю. А. Комп'ютерне тестування в навчальному процесі ВНЗ // Вісник Черкаського університету : наук. журнал. - Черкаси, 2013. - № 26 (279). -С. 32-37.

8. Кристопчук Т. С., Мельник Ю. В. Моніторинг стану викладання навчального предмета: Алгоритм вивчення. - "Молодий вчений", 2018 р. - С. 43-45

9. Лукіна Т.О. Педагогічна діагностика: завдання, методи, інструменти. - Київ : Проект "Рівний доступ до якісної освіти в Україні”, 2007. - 59 с.

10. Онопченко Г. В. Інтернет-тестування в інформаційному соціальному середовищі як інструмент - розвитку суб’єктів освітнього процесу. - Київ : Інститут об̆дарованої дитини НАПН У країни, 2013. 


\title{
References
}

1. Avanesov V. S. Formy testovyh zadanij. - Moskva: Centr testirovania, 2006. - $156 \mathrm{p}$.

2. Andrienko O. S. Diagnostuvannia v navczalnomu procesi // Visnyk Zaporizkogo dergavnogo universytetu.. - 2002.- №1.- P. 1-5.

3. Gensiorska M. M. Adaptyvne testuvannia v osviti // Informacijno-komunikacijni tehnologiji v osviti. -2014 . - №1

4. Gladka L. I. Systemnyj pidhid do ocinky jakosti znan' u formi kompiuternogo testuvannia. Naukovuj visnyk Donbasu, 2014. http://nvd.luguniv.edu.ua/archiv/NN26/index.html.

5. Eremeevych M. O. Kompjuterni systemy testuvannia ta jih analiz // Molodyj vchenyj. -2016 . - P. 330-332.

6. Ingekamp K Pedagogicheskaja diagnostika. - M. : Pedagogika, 1991. $-240 \mathrm{p}$.

7. Kornycka Ju. A. Kompiuterne testuvannia $\mathrm{v}$ navczalnomu procesi VNZ // Visnyk Cherkaskogo universytetu: nauk.zurnal. - Cherkasy, 2013. -№ 26 (279). - P. 32-37.

8. Krystopchuk T. Je., Melnyk Ju. V. Monitoryng stanu vykladannia navczalnogo predmetu: Algorutm vyvchennia. - Molodyj vchenyj, 2018. - P.43-45/

9. Lukina T.O. Pedagogichna diagnostyka: zavdannia, metody, instrument. - Kyiv : Proekt "Rivnyj dustup do jakisnoji osvity v Ukrajini", 2007. -59 p.

10. Onopchenko G. V. Internet-testuvannia v informacijnomu socialnomu seredovyshchi jak instrument rozvytku subjektiv osvitniogo procesu. - Kyiv : Instytut obdarovanoji dytyny NAPN Ukrajiny, 2013.

Одержкано статтю: 25.09.2019

Прийнято до друку: 18.10.2019

УДК $373.3 .016: 81-028.31$

DOI: $10.15330 /$ esu. 17.338-346

\author{
Лариса Круль, \\ кандидат педагогічних наук, доцент, \\ ДВНЗ "Прикарпатський національний \\ університет імені Василя Стефаника" \\ (м. Івано-Франківськ, Україна) \\ Larysa Krul, \\ Candidate of pedagogical sciences $(\mathrm{PhD})$, \\ Associate Professor, Vasyl Stefanyk Precarpathian \\ National university (Ivano-Frankivsk, Ukraine) \\ larisa-krul@ukr.net
}

Степан Недільський, кандидат педагогічних наук, доцент, ДВНЗ “Прикарпатський національний університет імені Василя Стефаника" (м. Івано-Франківськ, Україна)

Stepan Nedilskyi,

Candidate of pedagogical sciences $(\mathrm{PhD})$, Associate Professor, Vasyl Stefanyk Precarpathian National university (Ivano-Frankivsk, Ukraine) nedilsky.s@gmail.com

\section{ОСОБЛИВОСТІ ОРГАНІЗАЦЇ̈ МОВНО-ЛІТЕРАТУРНОЇ ОСВІТИ МОЛОДШИХ ШКОЛЯРІВ В УМОВАХ НУШ}

\author{
PECULIARITIES OF THE ORGANIZATION OF LINGUISTIC AND LITERARY \\ EDUCATION OF YOUNGER PUPILS IN THE CONDITIONS OF NEW UKRAINIAN \\ SCHOOL
}

В статті окреслено особливості організачії мовно-літературної освіти молодиих иколярів в умовах Нової украӥнської иколи з урахуванням нормативних документів, типових освітніх програм, методичних рекомендачій, авторських навчальних програм, підручників та посібників. 